\title{
PERUBUHAN PERUNTUKAN KAWASAN HUTAN MENJADI BUKAN KAWASAN HUTAN UNTUK MENAJAMIN HAK MASYARAKAT ATAS TANAH
}

\author{
Dede Frastien \\ Wahana Lingkungan Hidup Bengkulu \\ Email : frestiend@gmail.com
}

\begin{abstract}
Forest area damage continues to occur due to various factors including weak control and supervision of the operation of the licensing system in the management of forest areas, conversion of functions, conversion of forest areas to plantations, settlements and / or other non-forestry interests (Mining). the expected results of this paper are knowing and understanding related to the mechanism of implementing the Land Object of Agrarian Reform in Forest Areas based on Government Regulation Number 88 of 2017 and inhibiting factors in the application of Land Objects for Agrarian Reform in Forest Areas based on Presidential Regulation Number 88 of 2017. This paper is writing normative law using the case approach method. The results obtained, namely, comprehensive socialization regarding the mechanism regulated in LHK Ministerial Regulation Number 83 of 2016 concerning Social Forestry must be sought. Through the schemes offered by LHK Minister Regulation No. 83 of 2016 concerning Social Forestry, the community can contribute greatly and partner in maintaining the preservation and protection of forest areas and improving the economy. Concerns about the implementation of Presidential Regulation No. 88 of 2017 are the inclusion of extractive industry interests and the loss of managed areas of the people which have been maintained for generations.
\end{abstract}

Keywords :Forest; Agraria; Refom; Management; Sosial

\begin{abstract}
ABSTRAK
Laju kerusakan kawasan hutan terus terjadi disebabkan oleh berbagai faktor diantaranya yakni lemahnya pengendalian dan pengawasan terhadap operasionalisasi sistem perizinan dalam pengelolaan kawasan hutan, alih fungsi, alih fungsi kawasan hutan menjadi perkebunan, pemukiman dan/atau untuk kepentingan non kehutanan lainnya (Pertambangan). Tujuan yang ingin dicapai dalam tulisan ini yaitu mengetahui dan memahami terkait dengan mekanisme penerapan Tanah Objek Reforma Agraria dalam Kawasan Hutan berdasarkan Peraturan Presiden Nomor 88 Tahun 2017 dan Faktor penghambat dalam penerapan Tanah Objek Reforma Agraria dalam Kawasan Hutan berdasarkan Peraturan Presiden Nomor 88 Tahun 2017. Tulisan ini merupakan penulisan hukum normatif dengan menggunakan metode pendekatan kasus. Hasil yang didapatkan yaitu, sosialisasi secara komprehensif terkait mekanisme yang diatur dalam Permen LHK Nomor 83 Tahun 2016 tentang Perhutan Sosial harus lebih diupayakan. Melalui skema-skema yang ditawarkan Permen LHK Nomor 83 Tahun 2016 tentang Perhutan Sosial, masyarakat dapat berkontribusi besar dan bermitra dalam menjaga pelestarian dan perlindungan kawasan hutan serta peningkatan ekonomi. Kekhawatiran dari implementasi Perpres Nomor 88 Tahun 2017 adalah masuknya
\end{abstract}


kepentingan industri ekstraktif dan hilangnya wilayah kelola rakyat yang selama ini dijaga secara turun temurun.

\section{Kata Kunci : Hutan; Agraria; Reformasi ; Pengelolaan; Sosial}

\section{Pendahuluan}

Keanekaragaman sumber daya alam hayati yang berbentuk dalam suatu ekosistem saling mempunyai keterkaitan, ketergantungan antara satu dengan yang lain seyogyanya dijaga keberadaan dan kesinambungannya agar tetap berada dalam kondisi selaras, serasi dan seimbang. Itulah sebabnya Pasal 33 ayat (3) Undang-Undang Dasar Negara Republik Indonesia Tahun 1945 sejak dini telah meletakan landasan konstitusional pemanfaatan sumber daya alam hayati dan ekosistemnya di Indonesia. ${ }^{1}$ Kawasan hutan adalah wilayah tertentu yang ditunjuk dan/atau ditetapkan oleh pemerintah untuk dipertahankan keberadaannya sebagai hutan tetap. Kawasan hutan Negara, statusnya secara hukum bahwa hutan tersebut hutan milik Negara. Kawasan hutan Negara tidak selalu berhutan, sehingga peningkatan kawasan hutan dapat berarti secara hukum kawasan hutan Negara naik jumlahnya. Pada tahun 1984 kawasan hutan Negara ditetapkan berdasarkan Tata Guna Hutan Kesepakatan (TGHK) pada tahun 1997 kawasan hutan

\footnotetext{
1 Abdulah Marlang dan Rina Maryana, Hukum Konservasi Sumber Daya Alam Hayati dan Ekosistemnya, Mitra Wacana Media, Jakarta, 2015, hlm. 7.
}

Negara setelah dilakukan paduserasi antara TGHK dengan RTRWP. ${ }^{2}$

Kawasan Hutan terbagi menjadi dua yaitu Kawasan Hutan Konservasi dan Kawasan Hutan Lindung, kawasan hutan konservasi terbagi lagi menjadi 2 yaitu Hutan konservasi terdiri dari kawasan hutan Suaka Alam (KSA) berupa Cagar Alam (CA) dan Suaka Margasatwa (SM); Kawasan hutan Pelestarian Alam (KPA) berupa Taman Nasional (TN), Taman Hutan Raya (Tahura) dan Taman Wisata Alam (TWA); dan Taman Buru (TB). Kawasan hutan Suaka Alam (KSA) adalah hutan dengan ciri khas tertentu yang mempunyai fungsi pokok sebagai kawasan pengawetan keanekaragaman tumbuhan dan satwa serta ekosistemnya, dan juga berfungsi sebagai wilayah sistem penyangga kehidupan. ${ }^{3}$ Kawasan hutan lindung juga terbagi lagi antara lain Hutan Lindung, Hutan Produksi Terbatas, Hutan Produksi dan Hutan Konversi Produksi.

Upaya perlindungan dan pengelolaan lingkungan hidup yang didasarkan pada norma-norma lingkungan berarti secara seimbang antara kepentingan ekonomi, pelestarian fungsi lingkungan dan kondisi

\footnotetext{
2 Iskandar, Hukum Kehutanan, CV. Mandar Maju, Bandung, 2015, hlm 1

${ }^{3}$ Ibid, hlm. 2.
} 
sosial. Perlindungan dan pengelolaan dilakukan secara terpadu mencakup seluruh bidang-bidang lingkungan hidup untuk keberlanjutan fungsi lingkungan hidup. Pada akhirnya keseimbangan dan keberlanjutan akan tercapai kesejahteraan masyarakat. Dalam perlindungan dan pengelolaan lingkungan hidup, administrasi negara merupakan pihak yang dominan. Dominannya pemerintah merupakan konsekuensi dari sebuah negara kesejahteraan. $^{4}$

Laju kerusakan kawasan hutan terus terjadi disebabkan oleh berbagai faktor seperti penebangan liar (Ilegal logging), Kebakaran Hutan, lemahnya pengendalian dan pengawasan terhadap operasionalisasi sistem perizinan dalam pengelolaan kawasan hutan, alih fungsi, alih fungsi kawasan hutan menjadi perkebunan, pemukiman dan/atau untuk kepentingan non kehutanan lainnya (Pertambangan), yang tidak dapat dipungkiri kesemuanya itu telah menyebabkan terjadinya kerusakan dan kehancuran terhadap sumber daya hutan. Selama ini Negara hanya memdang kerusakan dan kekritisan kawasan hutan hanya disebabkan oleh warga Negara Indonesia yang memanfaatkan kawasan hutan yang disebut oleh Negara adalah perambah, faktanya kontribusi paling besar terhadap laju

\footnotetext{
${ }^{4}$ Helmi, Helmi, Hukum Perizinan Lingkungan Hidup, Cetakan Pertama, Sinar Grafika, Jakarta, 2012, hlm. 46.
}

kerusakan kawasan hutan adalah Kegiatan non Kehutanan (Pertambangan) dan Perkebunan skala besar yang dilakukan oleh korporasi untuk mengeksploitasi Sumber daya hutan dengan dalil izin pinjam pakai kawasan hutan (IPPKH).

Dalam Undang-undang Nomor 41 Tahun 1999 tentang Kehutanan, pada Pasal 19, istilah alih fungsi dikenal sebagai perubahan peruntukan dan fungsi kawasan hutan; Perubahan peruntukan kawasan hutan, terjadi melalui proses tukar-menukar kawasan hutan dan pelepasan kawasan hutan. Alih fungsi kawasan hutan, yang terjadi melalui perubahan peruntukan kawasan hutan terfokus untuk mendukung kepentingan di luar kehutanan (pertanian, perkebunan, transmigrasi, pengembangan wilayah, dan non kehutanan lainnya). Alih fungsi kawasan hutan dapat pula melalui perubahan fungsi hutan namun tidak mengurangi luas kawasan hutan, misalnya untuk tujuan pembangunan kehutanan (konservasi kawasan hutan alam/tanaman, hutan pendidikan/penelitian). Kerusakan kawasan hutan disebabkan oleh beberapa faktor. Salah satu faktor yang menarik untuk dikaji yaitu persoalan perubahan (alih) kawasan hutan, guna menghindari kerusakan kawasan hutan. Pelaksanaan kebijakan perubahan peruntukan, perubahan fungsi, dan penggunaan (izin pinjam pakai) kawasan hutan, sarat dengan pelanggaran dan penyimpangan baik yang bersifat prosedural 
maupun substansial, dan tidak Nomor 88 Tahun 2017 tentang Penyelesaian diaktualisasikannya prinsip hukum Penguasaan Tanah Dalam Kawasan Hutan.

pelestarian fungsi lingkungan hidup. ${ }^{5}$

Masyarakat sering disalahkan dalam kerusakan kawasan hutan, padahal masyarakat lebih dahulu berada dalam kawasan Hutan tersebut secara turun temurun, Padahal apabila dilihat lebih dalam bahwa pemerintahlah yang sering salah dalam penunjukan batas kawasan hutan, sehingga terjadi tumpang tindih terhadap wilayah kelola rakyat yang sudah dikelola secara turun temurun. Dari penjelasan tersebut bahwa Landasan yuridis dalam pelaksanaan kegiatan perubahan fungsi kawasan hutan mengacu pada pasal 19 ayat (1) Undang-Undang Nomor 41 tahun 1999 tentang Kehutanan yaitu "Perubahan peruntukan dan fungsi kawasan hutan ditetapkan oleh pemerintah didasarkan pada hasil penelitian terpadu. Mekanisme yang mengatur perubahan fungsi kawasan hutan didasarkan atas Keputusan Menteri Kehutanan No 70/KPTS-II/2000”. Dan juga Peraturan Pemerintah Nomor 104 Tahun 2015 tentang Tata Cara Perubahan Peruntukan dan Fungsi Kawasan Hutan, selain itu dari rezim saat ini lahirlah kebijakan baru yaitu Peraturan Presiden

\footnotetext{
${ }^{5}$ Iskandar, "Aktualisasi Prinsip Hukum Pelestarian Fungsi Lingkungan Hidup Dalam Kebijakan Perubahan Peruntukan, Fungsi, dan Penggunaan Kawasan Hutan", Jurnal Dinamika Hukum, Vol. 11 No. 3, 2011, hlm.3-4.
}

Sehingga dari penjelasan tersebut diatas penulis akan melakukan analisis terkait penguasaan tanah dalam kawasan hutan oleh masyarakat, bahwa Pelepasan kawasan hutan atau alih fungsi kawasan hutan untuk Masyarakat yang telah terlanjur berada di dalamnya merupakan nawacita Presiden Joko Widodo di era saat ini, namun hal tersebut harus melalui mekanisme-mekanisme yang telah di sepakati. Tulisan ini akan membahas tentang Bagaimana mekanisme penerapan Tanah Objek Reforma Agraria dalam Kawasan Hutan berdasarkan Peraturan Presiden Nomor 88 Tahun 2017 dan Apa Faktor penghambat dalam penerapan Tanah Objek Reforma Agraria dalam Kawasan Hutan berdasarkan Peraturan Presiden Nomor 88 Tahun 2017. Tujuan yang ingin dicapai dalam tulisan ini yaitu mengetahui dan memahami terkait dengan mekanisme penerapan Tanah Objek Reforma Agraria dalam Kawasan Hutan berdasarkan Peraturan Presiden Nomor 88 Tahun 2017 dan Faktor penghambat dalam penerapan Tanah Objek Reforma Agraria dalam Kawasan Hutan berdasarkan Peraturan Presiden Nomor 88 Tahun 2017.

\section{Pembahasan}

Secara etimologis, kata agraria berasal dari kata bahasa Latin yang artinya sebidang tanah. Kata bahasa Latinaggrarius meliputi arti yang ada hubungannya dengan tanah, 
pembagian atas tanah terutama tanah umum, bersifat perdesaan. Kata reform merujuk pada perombakan, mengubah dan menyusun/ membentuk kembali sesuatu menuju perbaikan. ${ }^{6}$ Dengan demikian reforma agraria dapat diartikan secara sederhana sebagai penataan kembali struktur pemilikan, penguasaan, dan penggunaan tanah/ wilayah, demi kepentingan petani kecil, penyakap, buruh tani. Sementara pengertian reforma agrarian yang lebih lengkap adalah suatu upaya sistematik, terencana, dan dilakukan secara relatif cepat, dalam jangka waktu tertentu dan terbatas, untuk menciptakan kesejahteraan dan keadilan sosial serta menjadi pembuka jalan bagi pembentukan masyarakat baru yang demokratis dan berkeadilan, yang dimulai dengan langkah menata ulang penguasaan, penggunaan dan pemanfaatan tanah dan kekayaan alam lainnya, kemudian disusul dengan sejumlah program pendukung lain untuk meningkatkan produktivitas petani khususnya dan perekonomian rakyat pada umumnya. ${ }^{7}$

Prof. Boedi Harsono, sebagai salah satu pengguna terminologi land reform, menyebutkan bahwa land reform meliputi perombakan mengenai pemilikan dan penguasaan tanah serta hubungan-hubungan hukum yang bersangkutan dengan pengusahaan tanah. Reforma agraria

\footnotetext{
6 Osmar Mungkasa, "Reforma Agraria Sejarah, Konsep dan Implementasinya", hlm. 5.

7 Ibid, hlm. 6.
}

atau land reform, bahkan sebelum tahun 1960, telah menjadi dasar perubahanperubahan dalam struktur pertanahan hampir di seluruh dunia. Prinsipnya adalah tanahtanah agraria harus secara aktif diusahakan sendiri atau dipakai oleh pemiliknya. Prinsip tersebut diatur secara tegas di dalam UndangUndang Nomor 5 Tahun 1960 tentang Pokok Agraria (UUPA) yang menyebutkan bahwa setiap orang dan badan hukum yang mempunyai sesuatu hak atas tanah pertanian pada asasnya diwajibkan mengerjakan atau mengusahakannya sendiri secara aktif, dengan mencegah cara-cara pemerasan. Agar asas tersebut dapat diwujudkan, undangundang menjelaskan perlunya ketentuanketentuan khusus terkait, misalnya ketentuan tentang batas minimum luas tanah yang harus dimiliki oleh petani, supaya ia mendapat penghasilan yang cukup untuk hidup layak bagi diri sendiri dan keluarganya, ketentuan mengenai batas maksimum luas tanah yang boleh dipunyai dengan hak milik, agar dicegah tertumpuknya tanah di tangan golongan-golongan tertentu. ${ }^{8}$

Fenomena ketimpangan penguasaan dan pemilikan tanah yang semakin meningkat dan berpengaruh pada meningkatnya kemiskinan dan pengangguran dipedesaan, pada dasarnya tidak terlepas dari kebijakan pertanahan yang hanya focus pada

\footnotetext{
8 https://www.hukumproperti.com/tulisanpakar/reforma-agraria/ Diundah Pada Tanggal 3
} Desember 2018 Pukul 16:00 Wib. 
peningkatan produktivitas yang berujung pertumbuhan ekonomi. Sementara penataan aset produksi malah terabaikan, yang berakibat masyarakat marjinal semakin terabaikan dan kehilangan akses terhadap tanah. Kondisi ini yang menimbulkan konflik agraria baik berupa perselisihan tanah di tingkat rumah tangga petani, meningkatnya penguasaan tanah skala besar, konversi penggunaan tanah yang tidak terencana, tata ruang yang tidak konsisten dan tumpang tindih. Hal ini tidak hanya berdampak pada masyarakat secara langsung tetapi juga pada program pemerintah seperti ketahanan pangan, perumahan rakyat, dan lingkungan hidup.

\section{Perubahan Peruntukan Kawasan Hutan}

\section{Untuk Masyarakat}

Populasi adalah kumpulan individu suatu spesies yang mempunyai suatu potensi untuk berkembang biak antara individu dengan individu, jadi populasi dipandang sebagai suatu sisitem yang dinamis yang selalu melakukan hubungan jika jumlah individu tiap satuan luas bertambah dikatakan populasi naik, terjadilah persaingan (Kompetisi) perihal makanan, tempat tinggal dan kebutuhan hidup lainnya. Persaingan dapat menimbulkan efek ekologi dalam jangka pendek atau panjang, persaingan dapat meningkatkan daya juang untuk mempertahankan keberlangsungan hidup. Akibat ekologi ialah kelahiran, kelangsungan hidup dan pemindahan (emigrasi). ${ }^{9}$ Dampak dari naiknya populasi adalah kebutuhan manusia dalam mencari kebutuhan hidup dan ruang kelola untuk mempertahankan hidup, hal tersebut bergantung kepada ketersidiaan suatu ruang yang mendukung kehidupan manusia, manusia dalam hal ini masyarakaat sering tersingkir dan terintimidasi dari ruang-ruang yang ada untuk menunjang kehidupannya, masyarakat yang terdesak akibat hilangnya wilayah kelolanya akhirnya memutuskan untuk memanfaatkan kawasan lindung, ruang-ruang kelola masyarakat yang dirampas oleh kepentingan-kepentingan pembangunan dan kepentingan industri ekstraktif tersebut menyebabkan masyarakat harus mencari wilayah kelola baru untuk mempertahan keberlangsungan hidupnya.

Masyarakat yang kehilangan wilayah kelolanya tersebut memanfaatkan kawasan lindung, kawasan lindung dalam hal ini adalah Hutan Negara, untuk mempertahankan kehidupannya, Kawasan lindung mempunyai fungsi utama sebagai penyimpan cadanagan air, penstabilan debit air, pelindung daerah bawahnya dari kerusakan karena gejala alam,penyedia oksigen, penjaga spesies hewan tumbuhtumbuhan dari kepunahan. Kawasan lindung di pinggir pantai atau pinggir laut berfungsi menjaga garis pantai dari abrasi air laut dan

\footnotetext{
${ }^{9}$ A. Tresna Sastrawijaya, Pencemaran Lingkungan, Rineka Cipta, Surabaya, 1991, hlm. 14.
} 
tempat berkembang biaknya ikan dan spesies lainnya. $^{10}$

Untuk mencapai kesejahteraan sosial bagi seluruh rakyat Indonesia, sebenarnya konstitusi Negara Republik Indonesia telah meletakan landasannya yang tertuang dalam Pasal 33 ayat (2) UUD 1945 menyatakan: "Cabang-cabang produksi yang penting bagi negara dan yang menguasai hajat hidup orang banyak dikuasai oleh negara." dan Pasal 33 Ayat (3) UUD 1945 menyatakan: "Bumi dan air dan kekayaan alam yang terkandung di dalamnya dikuasai oleh negara dan dipergunakan untuk sebesarbesar kemakmuran rakyat". 11

Upaya perlindungan dan pengelolaan lingkungan hidup yang didasarkan pada norma-norma lingkungan berarti secara seimbang antara kepentingan ekonomi, pelestarian fungsi lingkungan dan kondisi sosial. Perlindungan dan pengelolaan dilakukan secara terpadu mencakup seluruh bidang-bidang lingkungan hidup untuk keberlanjutan fungsi lingkungan hidup. Pada akhirnya keseimbangan dan keberlanjutan akan tercapai kesejahteraan masyarakat. Dalam perlindungan dan pengelolaan lingkungan hidup, Negara merupakan pihak yang dominan, dominannya pemerintah

10 Robinson Tarigan, Perencanaan Pembangunan Wilayah, Edisi Revisi, Bumi Aksara, Jakarta, 2005, hlm. 60.

${ }^{11}$ Undang-Undang Dasar Negara Republik Indonesia Tahun 1945 merupakan konsekuensi dari sebuah negara kesejahteraan. $^{12}$

Keberadaan kawasan hutan tersebut merupakan hasil dari proses pengukuhan kawasan hutan, yang meliputi tahapan mulai dari penunjukan kawasan hutan, penataan batas kawasan hutan, pemetaan kawasan hutan dan penetapan kawasan hutan. Tingkatan-tingkatan tersebut mengandung konsekuensi hukum, sehingga secara de jure kawasan hutan akan ada setelah suatu kawasan minimal ditunjuk oleh Menteri Kehutanan sebagai kawasan hutan termasuk batas- batasnya walaupun batas tersebut masih di atas peta. ${ }^{13}$

Perubahan kawasan hutan adalah suatu proses perubahan terhadap suatu kawasan hutan tertentu menjadi bukan kawasan hutan atau menjadi kawasan hutan dengan fungsi hutan lainnya. Perubahan kawasan hutan terjadi akibat perubahan fungsi kawasan hutan menjadi fungsi lainnya, atau perubahan fungsi dalam fungsi pokok kawasan hutan, dan perubahan peruntukan kawasan hutan dari kawasan hutan menjadi bukan kawasan hutan serta penunjukan parsial areal penggunaan lain menjadi kawasan hutan. Ruang lingkup perubahan kawasan hutan meliputi: a. Perubahan fungsi kawasan hutan; b. Perubahan peruntukan kawasan hutan; c. Penunjukan parsial areal penggunaan lain

\footnotetext{
${ }^{12}$ Op.Cit, Helmi, , hlm. 46.

13 Basyuni Tahir, Penisbian Aspek Pidana Dalam Penyelesaian Konflik Kawasan Hutan, Artikel, 2009, hlm. 2-3.
} 
menjadi kawasan hutan. Tujuan Perubahan Fungsi Kawasan Hutan yaitu terwujudnya optimalisasi dan manfaat fungsi kawasan hutan secara lestari dan berkesinambungan. ${ }^{14}$

Perubahan Kawasan hutan untuk menjamin hak atas tanah bagi masyarakat yang berada di dalam kawasan hutan mempunyai mekanisme tersendiri, mekanisme tersebut diatur di dalam Peraturan Presiden Nomor 88 Tahun 2017 tentang Penyelesaian Penguasaan Tanah Dalam Kawasan Hutan, Salah satu program prioritas dari pemerintahan baru adalah reforma agraria, yang secara jelas tercantum dalam dokumen Visi Misi dan Program Aksi Jalan Perubahan untuk Indonesia yang Berdaulat, Mandiri dan Berkepribadian (Nawacita). Reforma agraria menjadi bagian kelima Nawacita, yaitu "kami akan meningkatkan kualitas hidup manusia Indonesia”. Salah satu peningkatan kualitas hidup bagi rakyat indonesia adalah Hak atas tanah dengan kata lain Tata Kuasa oleh rakyat terhadap tanahnya sendiri, penguasaan terhadap tanah didalam kawasan oleh masyarakat merupakan program utama yang didorong dalam nawacita tersebut agar tercapainya peningkatan ekonomi masyarakat yang berada di dalam kawasan hutan.

\footnotetext{
14 Iskandar, dkk, Kebijakan Perubahan Kawasan Hutan Dalam Pengelolaan Berkelanjutan, Unpad Press, Bandung, 2011, hlm .14-15.
}

\section{Konstitusi Agraria}

Konstitusi agraria merupakan konstitusi yang berisi landasan mengenai hubungan antara negara dan warga negara terhadap tanah dan sumber daya alam lainnya. Istilah Konstitusi Agraria merupakan istilah baru baik dalam kajian konstitusi maupun kajian agraria. Konstitusi agraria menjembatani kedua bidang kajian antara kajian konstitusi dengan kajian agraria untuk melihat bagaimana konstitusi pada suatu negara merumuskan bagaimana keadilan agrarian dan hubungan-hubungan keagrariaan menyangkut penguasaan, pemilikan, penggunaan dan pemanfaatan dan pengelolaan tanah dan sumber daya alam lainnya dalam dokumen konstitusinya. ${ }^{15}$

Hubungan keagrariaan antara negara dan warga negara atas tanah dan sumber daya alam lainnya merupakan hal pokok yang menjadi dasar berdirinya suatu negara. Tanah dan sumber daya alam lainnya merupakan wilayah yang menjadi unsur keberadaan suatu negara. Tanpa diatur di dalam konstitusi pun, hubungan penguasaan antara negara terhadap tanah dan sumber daya alam lainnya telah ada. Tetapi beberapa negara menegaskan hubungan penguasaan negara terhadap tanah dan sumber daya alam lainnya dalam kaitannya dengan sistem ekonomi yang hendak dibangun, konstitusi agraria dijadikan sebagai landasan untuk melakukan

\footnotetext{
${ }^{15}$ Yance Arizona, Konstitusionalisme Agraria, STPN Press, Yogyakarta, 2014, hlm. 3
} 
reforma agraria sebagai konsekuensi perkembangan kehidupan bernegara. ${ }^{16}$

Negara Republik Indonesia telah meletakan landasannya yang tertuang dalam Pasal 33 ayat (2) UUD 1945 menyatakan: "Cabang-cabang produksi yang penting bagi negara dan yang menguasai hajat hidup orang banyak dikuasai oleh negara." dan Pasal 33 Ayat (3) UUD 1945 menyatakan:

"Bumi dan air dan kekayaan alam yang terkandung di dalamnya dikuasai oleh negara dan dipergunakan untuk sebesarbesar kemakmuran rakyat”. ${ }^{17}$ Sehingga dalam penerapan konsep Tanah Objek Reforma Agraria yang berada dalam kawasan hutan demi tercapainya keadilan sosial bagi seluruh rakyat Indonesia dan juga khususnya untuk peningkatan ekonomi masyarakat yang berada dalam kawasan hutan, maka Konstitusi Indonesia sebenarnya telah menjamin Hak-Hak tersebut.

Perubahan Peuntukan Kawasan Hutan dan Alih Fungsi Kawasan Hutan

Secara yuridis perubahan peruntukan, fungsi, dan penggunaan kawasan hutan memang dimungkinkan, meski dalam pelaksanaannya sarat dengan penyimpangan dan pelanggaran, sebagaimana telah diuraikan di muka. Pertanyaan yang timbul kemudian dilihat dari aspek sosiologis dan filosofis yaitu apakah suatu kawasan hutan

\footnotetext{
${ }^{16} \mathrm{Ibid}$, hlm. 4

${ }^{17}$ Undang-Undang Dasar Negara Republik Indonesia Tahun 1945
}

dapat diubah peruntukan dan fungsinya atau tidak, jawabannya harus dilihat dari sisi dinamika pembangunan, sosial, dan perkembangan teknologi. Sudah menjadi hukum alam bahwa tidak ada yang abadi dalam kehidupan ini. Artinya, segala sesuatu memiliki peluang besar untuk mengalami perubahan. Demikian pula dengan keberadaan kawasan hutan, perubahan peruntukan dan fungsi suatu kawasan hutan (kawasan hutan menjadi bukan kawasan hutan atau sebaliknya) sangat mungkin terjadi, baik itu terhadap kawasan hutan konservasi, hutan produksi ataupun kawasan hutan lindung. ${ }^{18}$

Sangat penting untuk diperhatikan yaitu bagaimana mengatur pemanfaatan kawasan hutan yang tepat, terkait dengan manfaat secara ekonomi dan sosialnya tanpa meninggalkan fungsi ekologisnya. Dalam kebijakan, harus betul-betul dipertimbangkan seberapa besar nilai manfaat yang bisa didapatkan dengan adanya perubahan peruntukan, fungsi dan penggunaan kawasan hutan, karena bila tidak, maka yang terjadi justru mendatangkan bencana lingkungan yang lebih besar. Aspek lain yang tidak kalah pentingnya yaitu penegakan hukum terhadap pelanggaran peraturan perundang- undangan, penyalahgunaan wewenang dan atau

18

http://www.korantempo.comdanBisnis//krn,20080508, 14.id.html Diunduh Pada Tanggal 5 Desember 2018, pukul 19:00 Wib. 
perbuatan melanggar prinsip hukum pelestarian fungsi lingkungan hidup. ${ }^{19}$

Dalam kebijakan perubahan peruntukan, fungsi dan penggunaan kawasan hutan masih sarat dengan polemik dan kontroversi, baik menyangkut lemahnya instrumen pengaturan (persoalan sinkronisasi dan harmonisasi),

belum diimplementasikannya prinsip pelestarian fungsi lingkungan hidup dalam kebijakannya, lemahnya keterpaduan kebijakan lintas sektor, lintas wilayah, dan lintas pemangku kepentingan, penyimpangan atau pelanggaran di lapangan, ataupun penyalahgunaan wewenang dari pihak-pihak yang terlibat dalam pengambilan keputusan, sehingga dipandang perlu dilakukan pengkajian lebih mendalam, guna menganalisis isu hukum terkait dengan kebijakan perubahan kawasan hutan sebagaimana telah dikemukakan di atas. Sehingga pemerintah tidak lagi sembarangan dalam melakukan pelepasan kawasan hutan, kawasan hutan harusnya dilepaskan untuk kepentingan kesejahteraan masyarakat bukan untuk pembangunan ataupun investasi yang berdampak terhadap lingkungan.

\section{Mekanisme Penerapan Tanah Objek} Reforma Agraria Dalam Kawasan Hutan Berdasarkan Peraturan Presiden Nomor 88 Tahun 2017.

19 Op. Cit, Iskandar, dkk, Kebijakan Perubahan Kawasan Hutan Dalam Pengelolaan Berkelanjutan, hlm. 24.
Kebijakan dan penegakan kebijakan (enforcement) dengan contoh demikian rupa menunjukan bahwa kita masih terlalu berat sebelah pada aspek-aspek ekonomi, tetapi pada pengaruh sampingannya belum kita konsepkan jelas dalam kaitan kebijakan maupun dalam ketegasannya. Ambisi-ambisi pembangunan seharusnya jangan hanya didasari pada angka-angka pertumbuhan yang bermotif ekonomi, tetapi semua faktor kepentingan yang masih bersinggungan dengan aspek-aspek kehidupan, termasuk tata ekologi, tetap menjadi perhitungan dan pertimbangan terpadu satu dengan lainnya. Politik pembangunan harus pula diikuti dengan politik lingkungan yang konkrit dan terpadu. ${ }^{20}$ Pada Rezim saat ini kebijakan pertanahan diarahkan pada "tanah untuk keadilan dankesejahteraan rakyat". Periode ini ditandai dengan kebijakan penertiban tanah terlantar, penyelesaian sengketa, redistribusi tanah, peningkatan legalisasi aset-tanah masyarakat yang diimplementasikan melalui Reforma Agraria. $^{21}$

$$
\text { Namun penerapan ataupun }
$$
implementasi dari Tanah Objek Reforma Agraria dalam kawasan hutan bertentangan dengan beberapa asas perndungan dan pelestarian kawasan hutan, Tujuan

\footnotetext{
${ }^{20}$ N.H.T. Siahaan, Hukum Lingkungan dan Ekologi Pembangunan,Edisi Kedua, Erlangga, Jakarta, 2004, hlm.73.

${ }^{21}$ www.bpn.go.id diakses pada tanggal 6 Desember 2018 Pukul 19:00 Wib.
} 
perlindungan hutan yakni, untuk menjaga kelestarian hutan agar dapat memenuhi fungsinya. Disadari bersama fungsi hutan sangat besar pengaruhnya didalam proses kehidupan makhluk bumi. Terutama bagi, kehidupan manusia sebagai khalifah dan penentu pelestarian ekosistem dalam rangka pelaksanaan pembangunan nasional. Bahkan lebih jauh kehidupan ekosistem yang diperankan di dalam kehidupan bangsa tidak terlepas dari ekosistem bumi yang sangat kompleks dan maha luas. Segi perlindungan hutan secara umum diarahkan, pada tanahtanah kawasan hutan dalam kesatuan ekosistem lingkungan hidup, salah satu kegiatan yang dilaksanakan bagi pencapaian tujuan perlindungan hutan antara lain, bahwa setiap areal hutan yang ditunjuk Pemerintah, dilakukan penataan batas terlebih dahulu. Hal ini dilakukan untuk menjamin adanya kepastian hukum kawasan hutan. ${ }^{22}$

Sehingga didalam Peraturan Presiden Nomor 88 Tahun 2017 pada pasal 3 ayat (1) menyatakan bahwa kawasan hutan yang dimaksud adalah kawasan hutan yang baru sebatas penunjukan bukan kawasan hutan yang telah ditetapkan, sehingga kawasan hutan yang belum ditetapkan pada prinsipnya dapat dilakukan pelepasan melalui mekanisme inventarisir masyarakat yang berada di dalamnya, sehingga masyarakat

\footnotetext{
${ }^{22}$ Alam Setia Zain, Alam Setia Zein, Hukum Lingkungan Konservasi Hutan, Renika Cipta, Jakarta, 1997, hlm.10.
}

yang telah terlanjur berada di dalam kawasan Hutan hanya dapat melakukan kemitraan melalui hak akses saja yang diatur didalam Peraturan Menteri LHK Nomor 83 Tahun 2016 tentang Perhutanan Sosial agar masyarakat sama-sama melindungi dan melestarikan lingkungan hidup. Capra mengatakan, untuk mengatasi krisis dan bencana lingkungan hidup, kita harus membangun masyarakat kita sebagai sebuah masyarakat berkelanjutan dengan berpolakan dan bersumberkan model ekosistem yang berkelanjutan. ${ }^{23}$

Dalam bukunya filsafat Lingkungan Sony Keraf berpendapat, Pemberdayaan Masyarakat secara berkelanjutan kalau terjalin kemitraan dan kerja sama di antara berbagai anggota dan kelompok masyarakat. Capra lalu mengaitkan kemitraan dalam komunitas manusia dengan demokrasi yang dibangun di atas dasar pemberdayaan setiap anggota yang memungkinkan setiap anggota dapat ikut berpartisipasi secara aktif, sukarela dan bebas untuk memainkan peran penting dalam perkembangan setiap anggota yang pada gilirannya berkontribusi bagi perkembangan komunitas. ${ }^{24}$

Sehingga Prinsip-prinsip diatas tersebut memberikan peluang bagi masyarakat untuk meningkatkan ekonominya melalui Peraturan

23 Fritjof Capra, The Wfrb of Life. A New Understanding of Living Systems, Flamingo London, 1997, hlm. 203-204.

${ }^{24}$ A. Sony Keraf, Filsafat Lingkungan Hidup "alam sebagai ssebuah kehidupan”, PT. Kanisius, Yogjakarta, 2014, hlm. 135. 
Presiden Nomor 88 Tahun 2017 tentang Penyelesaian Penguasaan Tanah dalam Kawasan Hutan bagi masyarakat yang telah terlanjur mengelola kawasan hutan yang status nya masih penunjukan, sedangkan pilihan lain bagi masyarakat yang berada di dalam kawasan hutan dan/atau telah mengelola kawasan hutan yang statusnya sudah penetapan pemerintah tetap memberikan akses kepada masyarakat tersebut melalui Peraturan Menteri Lingkungan Hidup dan Kehutanan Nomor 83 Tahun 2016 tentan Perhutanan Sosial, Pemerintah menawarkan 5 Skema dalam peraturan tersebut antara lain, Hutan Kemasyarakatan, Hutan Desa, Hutan Adat, Hutan Tanaman Rakyat dan Kemitraan Lingkungan, akses perhutanan ini tidak dapat dimiliki secara individu namun harus diberikan kepada kelompok tujuannya agar masyarakat dan pemerintah sama-sama menjaga kawasan hutan dan masyarakat dapat meningkatkan ekonominya agar terwujudnya kesejahteraan sosial bagi seluruh rakyat indonesia seperti yang diamanatkan oleh UUD Negara Republik Indonesia Tahun 1945.

Faktor penghambat dalam penerapan Tanah Objek Reforma Agraria dalam Kawasan Hutan berdasarkan Peraturan Presiden Nomor 88 Tahun 2017.
Faktor Penghambat dalam mengimplementasikan Tanah Objek Reforma Agraria dalam Kawasan Hutan adalah masyarakat masih salah pengertian terhadap pelepasan kawasan tersebut, yang dimaksud dengan pelepasan kawasan adalah hanya sebidang tanah yang telah dikuasai secara fisik bukan seluruh kawasan hutan, dan juga kawasan hutan yang dapat dijadikan objek Reforma Agraria adalah hutan negara yang statusnya sebatas penunjukan kawasan, bukan penetapan. Selanjutnya asas-asas perlindungan dan pelestarian lingkungan hidup juga kontradiktif terhadap kebijakan tersebut. Perlindungan kawasan dijadikan agenda prioritas dengan alasan laju deforestasi yang berimplikasi pada degradasi fungsi ekologis kawasan hutan, respon negara-negara lain dalam bentuk ke- bijakankebijakan ekonomi dan perda- gangan ekspor kehutanan Indonesia, dan pembuktian janji Indonesia pada dunia untuk mengurangi emisi karbon dari de- forestasi dan degradasi sampai tahun $2020 .^{25}$

Dikutip dari jurnal Mongabay.com, Faktor penghambat dalam mengimplementasikan Peraturan Presidan Nomor 88 Tahun 2017 adalah Kriteria Tora masih top-down, tidak sesuai prinsip dan

\footnotetext{
25 Ari Wibowo, 2013,"Kajian penurunan emisi gas rumah kaca sector kehutanan untuk mendukung kebijakan Perpres No. 61/2011". Jurnal Analisis Kebijakan Kehutanan, Vol. 10 No. 3, hlm. 235-254.
} 
tujuan pokok reforma agraria. "Lokasi-lokasi yang ditunjuk pemerintah melalui KLHK sebagai Tora belum menyasar lokasi yang selama ini mengalami konflik agraria dan tumpang tindih masyarakat dengan klaim kawasan hutan," katanya. Data KPA menyebut, 2015-2016 terjadi 702 konflik agraria di lahan 1.665.457 hektar dan mengorbankan 195.459 keluarga petani. Dalam periode itu juga terjadi kriminalisasi menyebabkan 455 petani ditahan, 229 mengalami kekerasan dan 18 orang tewas. "Ribuan konflik agraria di Indonesia tak terurus dan belum menjadi bagian dari pelaksanaan reforma agraria. Ini berdampak pada terlanggarnya hak-hak masyarakat dan terus kriminalisasi," Masalah penetapan Tora, katanya, masih pakai UU Kehutanan hingga Jawa, Bali dan Lampung, tertutup rapat dari jalan reforma agraria. Dalih pemerintah, ketiga wilayah itu tutupan hutan sama atau kurang $30 \%{ }^{26}$

Secara yuridis perubahan peruntukan, fungsi, dan penggunaan kawasan hutan memang dimungkinkan, meski dalam pelaksanaannya sarat dengan penyimpangan dan pelanggaran, sebagaimana telah diuraikan di muka. Pertanyaan yang timbul kemudian dilihat dari aspek sosiologis dan filosofis yaitu apakah suatu kawasan hutan dapat diubah peruntukan dan fungsinya atau

26

http://www.mongabay.co.id/2017/10/31/implementasi -reforma-agraria-masih-jauh-dari-harapan/ diundah pada tanggal 6 Desember 2018 pukul 20:00 Wib tidak, jawabannya harus dilihat dari sisi dinamika pembangunan, sosial, dan perkembangan teknologi. Sudah menjadi hukum alam bahwa tidak ada yang abadi dalam kehidupan ini. Artinya, segala sesuatu memiliki peluang besar untuk mengalami perubahan. Demikian pula dengan keberadaan kawasan hutan, perubahan peruntukan dan fungsi suatu kawasan hutan (kawasan hutan menjadi bukan kawasan hutan atau sebaliknya) sangat mungkin terjadi, baik itu terhadap kawasan hutan konservasi, hutan produksi ataupun kawasan hutan lindung.

Prof. Iskandar dalam bukunya Hukum Kehutanan mengembangkan 3 prinsip tentang Perlindungan yang saling menopang dan merupakan satu kesatuan dalam prinsip Perlindungan. Prinsip tentang Perlindungan kawasan hutan diantaranya, sebagai berikut: (1) Prinsip Keutuhan (Holistic); (2) Prinsip Keterpaduan (Integrated); (3) Prinsip Keberlanjutan/Kelestarian (Sustainability). ${ }^{27}$ Kebijakan perubahan peruntukan dan fungsi kawasan hutan sangat bertentangan dengan prinsip-prinsip diatas, bahwa keberlanjutan lingkungan hidup khususnya kawasan hutan dapat dinikmati oleh generasi ke genarasi dan dapat dinikmati oleh seluruh manusia di muka bumi ini dengan menjaga dan melestarikan keutuhan dan fungsinya. Sehingga resolusi yang paling baik adalah

\footnotetext{
${ }^{27}$ Iskandar, Hukum Kehutanan, Op.cit.,hlm.22.
} 
Pasal 1 ayat 1 Permen LHK Nomor 83 Tahun 2016 tentang Perhutanan Sosial, definisi perhutanan sosial adalah system pengelolaan hutan lestari yang dilaksanakan dalam kawasan hutan Negara atau hutan hak/hutan adat yang dilaksanakan oleh masyarakat setempat atau masyarakat hukum adat sebagai pelaku utama untuk meningkatkan kesejahteraannya, keseimbangan lingkungan dan dinamika sosial budaya dalam bentuk Hutan Desa (HD), Hutan Kemasyarakatan (HKm), Hutan Tanaman Rakyat (HTR), Hutan Adat (HA) dan Kemitraan Kehutanan. ${ }^{28}$ Sehingga pemerintah tidak lagi memandang bahwa masyarakat sebagai perambah namun pemerintah memandang masyarakat sebagai mitra untuk menjaga keberlangsungan dan keberlajutan lingkungan hidup. Karena diberikannya akses pengelolaan hutan tersebut tidak dapat dipindahtangankan terhadap kepentingan investor.

\section{Penutup}

Dalam melakukan Implementasi Tanah Objek Reforma Agraria dalam Kawasan Hutan seharusnya pemerintah mensosialisasikan secara komprehensif agar masyarakat dapat memilih mekanisme yang dapat dipakai apakah melalui Perhutanan Sosial atau Melalui skema TORA dalam Kawasan Hutan, karena masyarakat dapat

28 Peraturan Menteri Lingkungan Hidup dan Kehutanan Nomor 83 Tahun 2016 tentang Perhutanan Sosial. memberikan kontribusi besar terhadap kelestarian Hutan, sehingga implementasi dari Permen LHK Nomor 83 Tahun 2016 tentang Perhutan Sosial memberikan jawaban kepada pemerintah untuk tidak semestinya melakukan Perubahan peruntukan dan fungsi kawasan hutan yang sudah ditetapkan, melalui skema-skema yang ditawarkan Permen LHK Nomor 83 Tahun 2016 tentang Perhutan Sosial, masyarakat dapat berkontribusi besar dan bermitra dalam menjaga pelestarian dan perlindungan kawasan hutan serta peningkatan ekonomi, kekhawatiran dari implementasi Perpres Nomor 88 Tahun 2017 adalah masuknya kepentingan industri ekstraktif dan hilangnya wilayah kelola rakyat yang selama ini dijaga secara turun temurun.

\section{Daftar Pustaka}

\section{Buku}

Arizona, Y., (2014). Konstitusionalisme Agraria. Yogyakarta : STPN Press.

Capra, F.(1997). The Wfrb of Life. A New Understanding of Living Systems. London : Flamingo London.

Helmi. (2012). Hukum Perizinan Lingkungan Hidup. Cetakan Pertama. Jakarta : Sinar Grafika.

Juliantara. D. dan Fauzi. N. (2000) Menyatakan Keadilan Agraria. Jakarta : BPKPA.

Keraf, A.,S.. (2014). Filsafat Lingkungan Hidup "alam sebagai ssebuah kehidupan”. Yogyakarta : PT. Kanisius. 
Marlang, A. dan Maryana, R. (2015). Hukum Konservasi Sumber Daya Alam Hayati dan Ekosistemnya, Jakarta : Mitra Wacana Media.

Iskandar, dkk. (2011). Kebijakan Perubahan Kawasan Hutan Dalam Pengelolaan Berkelanjutan. Bandung : Unpad Press.

Iskandar. (2015). Hukum Kehutanan. Bandung : CV. Mandar Maju.

Sastrawijaya, A.Tresna. (1991). Pencemaran Lingkungan. Surabaya : Rineka Cipta.

Siahaan, N.H.T. (2004). Hukum Lingkungan dan Ekologi Pembangunan. Jakarta : Erlangga.

Tarigan, R., (2005). Perencanaan Pembangunan Wilayah. Jakarta : Bumi Aksara.

Zain, A.S., (1997). Hukum Lingkungan Konservasi Hutan. Jakarta : Renika Cipta.

\section{Jurnal}

Iskandar. (2011). Aktualisasi Prinsip Hukum Pelestarian Fungsi Lingkungan Hidup Dalam Kebijakan Perubahan

Peruntukan, Fungsi, dan Penggunaan Kawasan Hutan. Jurnal Dinamika Hukum, Vol. 11 No. 3.Hlm.3-4.

Wibowo, A. (2013). Kajian penurunan emisi gas rumah kaca sector kehutanan untuk mendukung kebijakan Perpres No. 61/2011. Jurnal Analisis Kebijakan Kehutanan, Vol. 10 No. 3, Hlm. 235254. 